\title{
A Constructive Teaching Model in Learning Research Concept for English Language Teaching Students
}

\author{
Khoirul Anwar ${ }^{1}$ \\ ${ }^{1}$ English Language Education Department, University of Muhammadiyah Gresik, Indonesia \\ Correspondence: Khoirul Anwar, University of Muhammadiyah Gresik, Jl. Sumatera 101 GKB Randu Agung \\ Gresik, Indonesia. E-mail: anwarkhoirul41@gmail.com
}

Received: November 26, $2014 \quad$ Accepted: January 6, $2015 \quad$ Online Published: April 27, 2015

doi:10.5539/ies.v8n5p62 URL: http://dx.doi.org/10.5539/ies.v8n5p62

\begin{abstract}
This is a study to focus on analyzing the use of constructive teaching method toward the students' motivation in learning content subject of Introduction to Research of English Language Teaching. By using a mix-method of qualitative and quantitative analysis, the data are collected by using questionnaire and classroom observation. The questionnaire is given to the twenty subjects of the fifth semester students at English Language Education department of University of Muhammadiyah Gresik who join the subject of Introduction to Research in English Language Teaching. The class had already undergone the implementation of a lesson study on the use of constructive teaching method handled by a team teaching of four lecturers. After the implementation, the class is observed and recorded to collect the qualitative data and then reduced, displayed, and drawn into research conclusion. The results show that the constructive teaching method had stimulated students' motivation in learning especially on the students' engagement in individual and group activities that is the more the students engaged the more motivated they are. The motivation, in fact, can be triggered by two complementary ways that is from individuals to members of the group or from the group to individuals. This study implied that the process of learning content course in English Language Teaching is highly important to be considered because this will automatically influence the students' motivation to learn and finally achieve the learning materials better.
\end{abstract}

Keywords: constructive teaching method, English language teaching, content course

\section{Introduction}

It is quite commonly understood that there are two kinds of teaching problems usually happened in English Language Teaching (ELT) classes that is about skill courses and the content course cases. A lots of research findings of the skill courses had shown the spirit of changing a better output of many settings in English for Foreign Language (EFL) classes but only few efforts are conducted to concern with the learning problems in content courses of the EFL classes shown by the limited research findings in that area.

Based on common experiences of teaching content courses in EFL classes, traditional ways of teaching by focusing on explanation and one way communication dominated by a lecture or a teacher still can be found easily in many settings of Indonesian Learners particularly. The assumptions of the common practices actually are normally based on the following reasons:

1) First, content means knowledge. Teachers argue that knowledge is always related to purely cognitive in that students cannot learn the knowledge comprehensively without any helps from teachers. Even some believe that learning without teachers is dangerous. This dogma, or whatever it is named, delivers the concept of teacher-centered learning authoritatively that let teachers dominantly seize their powerful authority in language classes so that they will always fulfill their wants and expectations rather than considering the students' needs and wants.

2) Second, content means complex and difficult. Since content course is a knowledge structured, then it stimulates assumption that it is commonly complex and difficult. This also creates deeper and wider impacts on books writers and material designers to always deliver complexities when composing teaching materials so that it sounds that the more complex the more scientific.

3) Third, content means permanent. To teach the content materials, teachers usually too much focus on transferring the knowledge to students so that the goal is just only to transfer this knowledge and the method 
of transferring itself is commonly ignored. This ignorance of considering teaching methodology causes impacts on students' creativities of learning in ELT classes, because teachers think that the method is already permanent that is just to make students master the teaching materials whatever the way they use to teach.

Those one hand dominant reasons had actually brought wide and negative impacts for English Educational Practices especially in EFL content course settings so that content is usually perceived given and static. The static process of teaching, therefore, usually brings about de-motivation of students in learning in that teaching materials and activities are influential on learning motivation (Babaee, 2012). The important influence of the materials and classroom activities on motivation had also been proven by Carreira (2006) in Japanese students that the changes of classroom activities had changed their motivation. Other researches also proved that the changes of motivation also influence learning outcomes (Bernaus \& Gardner, 2008; Thamimi \& Shuib, 2009; Vivian \& Marek, 2010; Bernaus, Wilson, \& Gardner, 2009).

The choices of learning activities recently become the most important concern to make student motivation and achievement better. Lasagabaster (2011) had developed Content and Language Integrated Learning (CLIL) that contributed highly on students' motivation and achievement. The similar findings on positive activities in classroom of Reza and Hossein (2013) also had influenced higher motivation and achievement. Even, Mifsud (2011) also had found that the high motivation of students is highly determined by high teacher efficacy in which the efforts of the teacher to always enhance professional development influence students learning motivation.

The ideas of teaching language enhancement primarily had been promoted for example by Hutchinson and Waters (1993) that proposed the changing paradigm from teacher-centered into Learning centered approach in that all aspects of learning should consider the student needs and wants including goals, activities, materials, and even the evaluation models of learning. In this case learning is much more on how students can learn how to adjust between individuals and society. Teachers can influence what they teach to students but students have their right to determine to learn.

The idea of combining and selecting the best method of teaching EFL actually has also been suggested by Murcia (2001) that teachers should be able to select properly or even combine selectively among the recent four methods such as cognitive approach (language is rule-governed cognitive behavior), affective-humanistic approach (learning a foreign language is a process of self-realization and of relating to other people), comprehension approach (language acquisition occurs if and only if the learner comprehends meaningful input), and communicative approach (the purpose of language is communication). The dynamic selection of the principles of language teaching methods is also suggested by Richards and Renandya (2002) that the language pedagogy is not quite static because teachers had changed various experiences that enrich the growing process of determining appropriate situation based on particular needs. Even the currents approached of teaching that have been found are not totally compatible with any teaching situations because of two reasons: first, mostly the methods being found are the reflection of a particular one's observation and experience. Second, most research in language acquisition focuses more on subjective interpretations rather than on giving conclusive evidence. Hockly (2011) also suggested that combining teaching language can also be done by blending techniques meaning that any method can be used in the class situation as long as it can stimulate the students' creativities.

So, there are at least two important things of determining the appropriate teaching strategy that is to fulfill the students' needs to determine their own learning and to best select and combine the current language teaching strategy that had been found by today's researchers.

Since the goal of learning is to maximize the students' capacity and to practice them with the real context of any situation, natural approach of teaching is considered appropriate to at least eradicate teaching problems of content course in English Language Teaching. Some people agree that this natural approach in content course subjects is also called a constructive teaching model. The constructivism model of learning is actually to give students opportunity and maximally explore and construct their knowledge based their interaction with environments. Marlowe and Page (2005) divine four basic situations to implement the constructivism model: The first basic principle is that learning is part of constructing knowledge not just receive it, so teaching is actually to help students construct their knowledge in the classroom. The second is that teaching is to provide thinking and analyzing activities not accumulating and memorizing process. This can be done by discussion, role-play, presentation etc. The third is that teaching and learning is about understanding and applying concept not repeating back the memories being slotted in mind. The last is that teaching is of being active in the class not be passive interactions.

Gagnon and Collay (2001) propose six elements to provide constructivism model of learning that is situation (before teaching, a teacher should build an appropriate situation), groupings (the activity in grouping should be 
determined first especially of the roles for individuals and members of the group), bridge (this is to know what the students already know about the concepts or not, so some games usually necessary in this process), questions (this is a phase where each student has widely opportunities to ask and explore questions), exhibit (this one of the most important process in the learning activities in that each individual has opportunity to share through presentation orally or in written), and the last is reflections (this is the place where analysis is conduced to see the weaknesses and the strengths of the students and the class situations to improve the next following process.

Gagnon and Collay (2001) also give three general application of having successful application in the constructivism teaching method that is discovery phase (this is to practice students analysis using hypothesis), concept introduction (this is to help students how to focus and think efficiently and effectively), and the last is concept application (students are required to apply their capability do solve real problems)

The strengths of the constructivism teaching methods had already triggered the team of Lesson Study to apply it in the content course of Introduction to Research in English Language Education at English Language Education Department for the setting of the fifth semester student at University of Muhammadiyah Gresik. This study, therefore, is intended to see the use of the constructive teaching method towards the students' motivation in learning research concepts.

\section{Method}

The subject of this study is twenty students joining the course of Research for English Language Teaching at University of Muhammadiyah Gresik. There are two models of instrument used to collect the data that is questionnaire and observation. The questionnaire consists of fifteen items reflecting the motivation of learning Research in Language Teaching with four groups of collecting information that is the first two items are about the expectation of joining research subject, items number three, four, five, six, and seven, are about Motivation to read research journal articles, items number eight, nine, ten, and eleven are about Motivation in learning research concept through discussion, items number twelve, thirteen, fourteen, and fifteen, are about Motivation in learning research concept through presentation.

The questionnaire is given to the twenty students of fifth semester student of English Language Education Department at University of Muhammadiyah Gresik as the intended subject of this study. The class of Research in English Language Teaching with the twenty subjects is also observed into four times to see their consistency in developing motivation of learning research.

The class has been organized into the implementation of constructivist teaching model by the principle of Lesson Study that is plan, do, and see. Because it is handled in a constructivist teaching procedure, a team teaching has been hold by four lecturers. In the phase of Plan, the team has formulated four meetings and has decided four lesson plans. Each meeting has been handled by each lecturer consecutively. In the phase of Do, one lecturer handles the class and the rests of the team record and observe the process of teaching and learning in the class. The last phase is See in that all lectures in the team discuss to see the weaknesses and the strength to make some improvements in the next following meetings.

To evaluate the improvements of the students' motivation in the class of Research in English Language Teaching, finally, the students are given a questionnaire that consists of fifteen items and they are also observed in the class. The results of the questionnaire are analyzed by using percentage. Meanwhile, the results of the observation are reduced, displayed, and then drawn to achieve the conclusion. In short, the data are analyzed quantitatively and qualitatively.

\section{Results and Discussions}

In this part, the study describes the results into two sections that are the results of questionnaire and observation. The finding of the fifteen items in the questionnaire with its four types of the grouping items can be presented in the descriptions below.

The first point is about the expectation of joining research subject. All respondents of the twenty students (100\%) reveal that the research course is very important. They also expect that after joining the subject they hopefully acquire the complete goals of research in English Language Education (100\%). The summary of the finding about the expectation of joining research subject.

The second point is about motivation to read research journal articles. The data show that sixteen students $(80 \%)$ are interested in their own research journals, ten of them (50\%) are interested in others. About their understanding of the general objectives of research journals, twelve students $(60 \%)$ agree but eight of them somewhat agree $(40 \%)$. In the understanding of research concept after reading research journals, fourteen students $(70 \%)$ agree but only six of them somewhat agree (30\%). This is quite similar also in the autonomous 
learning to find research concept in that fourteen students $(70 \%)$ agree and only six of them somewhat agree $(30 \%)$.

The third part is about motivation in learning research concept through discussion. The data reveal that all twenty students $(100 \%)$ agree to interest in group discussion. In term of always to initiate and share ideas in discussion, thirteen of them (65\%) agree but seven of them (25\%) somewhat agree. Twelve students $(60 \%)$ agree to actively engaged in the discussion even sixteen of them $(80 \%)$ agree that they can understand the research concept deeply after the discussion.

The last part is about motivation in learning research concept through presentation. The data show that twelve students $(60 \%)$ are interested in the presentation and they feel that they can build more confidence to share in the presentation. But half of twenty students feel confident to convince the audience (50\%) but fourteen of them still agree to argue that they get their understanding of the research concept through the presentation.

Based on the results of the four components in the questionnaire, it can be concluded that $71.6 \%$ of the twenty students feel that they have higher motivation to study research through the implementation of the natural approach of constructivist teaching model. The average of the students' responses can be seen at table 1 .

To support the quantitative data above, data from observation also show the trends of increasing motivation to learn research in English Language Teaching. The quotation below is a description of particular group discussion of the class teaching and learning situation in that the interactive understanding of the students brings about the high motivation in understanding research concept after constructively instructed:

Student 1: What is the subject? The teacher?

Student 2: The English Teacher...You mean...

Student 1: In Taiwan. Then, what is the design of the research in this journal? The behaviouristic method have influenced...

Student 3: the design I think is descriptive survey...

Student 2: yes I think it is a survey because there is a questionnaire...

Student 1: Ehm...Again... what is the design...

Student 2: Descriptive research design.... survey I think...because the method of collecting data by using a questionnaire.

Student 3: So what is the results?...

Student 1: The result is that there is positive influence on the use of... in Taiwanese students.

(The quote of observation scripts at the first meeting)

In the quotation, It is seen that the interaction of the learning is centered in a small group discussion by interchangeably share the ideas among the member of the group. No domination nor too directive instruction given by certain people too, in that everybody gives equal contribution to analyze the materials given by the lecturer to achieve their maximum goals. So, the most important lesson is that the constructive learning model naturally builds the students' motivation dynamically to encourage the individual engagement in the group. This is, therefore, had supported Richards and Renandya (2002) that teaching is to provide new experiences to enrich students development for their needs and wants.

Additionally the quotation below of classroom situation of student presentation after discussion in a group, show that they are very enthusiastic and motivated representing the group opinion:

Lecturer: ...Okay... who wants to present of the first group?...

Student 1: ...yes sir, Tanzil is the speaker...

Lecturer: ...Ok. Would you please stand up and present it in front.

Student 2: ... Okay guys Assalamualaikum. I want to explain about the research design of the pronunciation of segmented sounds at early childhood age. In this case, the research uses developmental study especially cross-sectional method because there is a comparison between students with one until two years old and the students of two until three years old. So I think this is a cross-sectional in developmental study......

Lecturer: ...Ok. Thank you. Now what about the other groups, do you agree that this is a developmental study...

(This is part of a quotation script at the second meeting)

The quotation above is other evidence that the motivation is triggered not only by the individuals but also by a group. It is known that the presenter in the quotation actually does not want to be firstly a representative of the group. But then the group already pushed him to immediately be a speaker therefore he is motivated to present the results of the discussion still because of his responsibility. So, the constructive model of learning has already 
encouraged them to be more responsible learners as well. In this case, students are firstly not intrinsically motivated to learn the materials, but after involving in the small group activities with constructive tasks given by the lecturer, finally they are more extrinsically motivated to be representative of the group. This is therefore regular to Chang (2005) finding on complementary effect between intrinsic and extrinsic motivation. Interestingly the complementary characteristic happens in a classroom setting in which friends and peers are much more powerful to influence.

Table 1. The total average of the students' response about motivation

\begin{tabular}{|c|c|c|c|c|}
\hline \multirow[b]{2}{*}{ Items } & & \multicolumn{3}{|c|}{ Results (in percentage) } \\
\hline & & Agree & $\begin{array}{l}\text { Some-what } \\
\text { Agree }\end{array}$ & Disagree \\
\hline \multirow{2}{*}{$\begin{array}{l}\text { The expectation of joining } \\
\text { research subject }\end{array}$} & $\begin{array}{l}\text { The importance of the research } \\
\text { course }\end{array}$ & 100 & 0 & 0 \\
\hline & $\begin{array}{l}\text { The expectation of acquiring the } \\
\text { goals of the course }\end{array}$ & 100 & 0 & 0 \\
\hline \multirow{5}{*}{$\begin{array}{l}\text { Motivation to read research } \\
\text { journal articles }\end{array}$} & $\begin{array}{l}\text { The interest of students' own } \\
\text { research journals }\end{array}$ & 80 & 20 & 0 \\
\hline & $\begin{array}{l}\text { The interest of research journals } \\
\text { from others }\end{array}$ & 50 & 50 & 0 \\
\hline & $\begin{array}{l}\text { Understanding the general } \\
\text { objectives of research journals }\end{array}$ & 60 & 40 & 0 \\
\hline & $\begin{array}{l}\text { Understanding research concept } \\
\text { after reading research journals }\end{array}$ & 70 & 30 & 0 \\
\hline & $\begin{array}{l}\text { Autonomous learning to find } \\
\text { research concept }\end{array}$ & 70 & 30 & 0 \\
\hline \multirow{4}{*}{$\begin{array}{l}\text { Motivation in learning research } \\
\text { concept through discussion }\end{array}$} & Interest to discuss in group & 100 & 0 & 0 \\
\hline & $\begin{array}{l}\text { Always initiate to share ideas in } \\
\text { discussion }\end{array}$ & 65 & 35 & 0 \\
\hline & Actively engaged in discussion & 60 & 40 & 0 \\
\hline & $\begin{array}{l}\text { Understand research concept from } \\
\text { discussion }\end{array}$ & 80 & 20 & 0 \\
\hline \multirow{4}{*}{$\begin{array}{l}\text { Motivation in learning research } \\
\text { concept through presentation }\end{array}$} & Interest to have a presentation & 60 & 40 & 0 \\
\hline & Self confidence to present & 60 & 40 & 0 \\
\hline & $\begin{array}{l}\text { Able to convince audience in } \\
\text { presentation }\end{array}$ & 50 & 50 & 0 \\
\hline & $\begin{array}{l}\text { Able to understand research } \\
\text { concept after presentation }\end{array}$ & 70 & 30 & 0 \\
\hline Average & & 71.6 & 35.4 & 0 \\
\hline
\end{tabular}

In term of interactions among the students in the groups, the constructive teaching by optimizing group presentation can build the students' responsibility to highly acquire group involvement so that they are not only motivated but also can master the materials well. This a quotation of a student presentation after discussion conducted in a small group to share with others in a larger situation in order to have mutual inputs so that they can learn a lot from the session.

Student 1: ...from this journal, ...eee...the type of research design is true experimental design because there are two variables that is independent and dependent variables. The independent variable is the impact of computer assisted language learning and dependent variable is the achievement of secondary students in German. Then, the numbers of sample are 112 students. How to take the sample? First, the students 
are divided randomly for experimental group and the control group. The last is the instrument of the research, there two instruments: the first is achievement test and the second is...program...

(This is a quotation script of the third meeting).

The quotation shows that the small group discussion session is actually help not only their motivation and participation develop in the class, but also push them of understanding the material in learning research in English language Teaching. The results are really consistent with previous findings conducted by Bernaus and Gardner (2008), Thamimi and Shuib (2009), Vivian WU and Marek (2010), Bernaus, Wilson, and Gardner (2009), and Reza and Hossein (2013), in that student motivation had greatly contributed to learning achievement. The finding also indicates that the varieties of classroom interaction with interactive and constructive strategies give more opportunities for students to engage intensively so that this supports the previous finding of Saefurrohman and Istikharoh (2012) saying that interactive activities mainly closing to the students needs (especially on e-learning activities) easily generate student motivation.

Of the finding, the explanation of the students above is actually the representation of the group work that really expresses the correct content of the materials they discuss already. Meaning that, through the implementation of constructive teaching model, the students can also increase their understanding of their research concepts as well.

\section{Conclusion}

From the findings and discussion above, it can be concluded that: constructive teaching method is a good strategy to motivate students' motivation in learning content courses such as learning research subject in English Language Teaching. In fact the strategy could dynamically contribute to the students' engagement in learning by optimizing their independent and autonomous atmosphere in the class setting such as by stimulations of individual and group analysis of Research Articles' Journals of their own interest and then let them discuss and present the result in the groups.

The research also concluded that in the implementation of constructive teaching method, the motivation of the students is built by two ways that is from individuals to group or from group to individuals. The meaning is that a good and motivated student always triggers other unmotivated students in the group. Meanwhile a motivated group will always encourage the unmotivated student as well. This can finally create more opportunities for independent and autonomous learning situation in all cases of content course subjects so that it reduces highly dominated teacher-centered learning.

The research automatically indicates the better trends of students' achievement in learning Research on English Language Teaching. It can be concluded that the high motivated individuals and members of the group learning could also influence their understanding in the learning concept materials of Research in Language Teaching autonomously.

In short, this study suggests pathways for other teaching practitioners to always consider students' needs and wants to deliver content materials, design, and evaluation in language teaching. The process of learning, therefore, is more important in any teaching and learning because a better process will always create better output of learning.

\section{References}

Babaee, N. (2012). Motivation in Learning English as a Second Language: A Literature Review. Canadian Journal for New Scholars in Education, 4(1).

Bernaus, \& Gardner. (2008). Teacher Motivation Strategies, Student Perceptions, Student Motivation, and English Achievement. The Modern Language Journal, 92(iii).

Bernaus, Wilson, \& Gardner. (2009). Teachers' motivation, classroom strategy use, students' motivation and second language achievement. JPOOSRÉT AM LAINNUGEULA VRUEMZ 12, junio 2009. Retrieved from http://www.ugr.es

Carreira, Matsuzaki, \& Junko. (2006). Motivation for Learning English as a Foreign Language in Japanese Elementary Schools. JALT Journal, 28(2). Retrieved from http://www.jalt-publications.org

Chang, H. H. (2005). The Relationship between Intrinsic/Extrinsic Motivation and Language Learning Strategies Among College Students of English in Taiwan. A Thesis in Applied English, College of Applied Languages, Ming Chuan University. Retrieved from http://www.ethesys.lib.mcu.edu.tw

Gagnon, Jr. G. W., \& Collay, M. (2001). Designing for learning: Six Elements in Constructivist Classrooms. Corwin Press, Inc, Thousand Oaks, CA, USA. 
Hockly, N. (2011). Five things you always wanted to know about blended learning (and were afraid to ask). In English Teaching Professional, 75(6), 58.

Hutchinson, T., \& Waters. (1993). English for Specific Purposes: A learning Centered approach. Glasgow: Cambridge University Press.

Lasagabaster, D. (2011). English achievement and student motivation in CLIL and EFL settings. Innovation in Language Learning and Teaching, 5(1), 3-18. http://dx.doi.org/10.1080/17501229.2010.519030

Marlowe, B. A., \& Page, M. L. (2005). Creating and sustaining the constructivist classroom (2nd ed.). Thousand Oaks, CA: Corwin Press.

Mifsud, M. (2011). The Relationship of Teachers' and Students' Motivation in ELT in Malta: A Mixed Methods Study. A thesis submitted to the University of Nottingham for the degree of Doctor of Philosophy. Retrieved from http://www.etheses.nottingham.ac.uk

Murcia, C. M. (2001). Teaching English as a second or Foreign Language. New York: Copyright by Heinle \& Heinle.

Reza, M., \& Hossein. (2013). The Role of EFL Teachers in Increasing High School Students' Motivation in Classroom. International Journal of Education and Research, 1(10).

Richards, J. C., \& Renandya, W. A. (2002). Methodology in Language Teaching: An anthology of current practice. New York: Cambridge University Press. http://dx.doi.org/10.1017/CBO9780511667190

Saefurrohman, \& Istikharoh, L. (2012). Implementing E-Learning for Increasing Student's Motivation in Learning English. ATIKAN, 2(1). Retrieved from http://www.atikan-jurnal.com

Thamimi, \& Shuib. (2009). Motivation and Attitudes towards Learning English: A Study of Petroleum Engineering Undergraduates at Hadhramout University of Sciences and Technology. GEMA Online Journal of Language Studies, 2.

Vivian, W. U., \& Marek. (2010). Making English a "Habit": Increasing Confidence, Motivation. TOJET: The Turkish Online Journal of Educational Technology, 9(4).

\section{Copyrights}

Copyright for this article is retained by the author(s), with first publication rights granted to the journal.

This is an open-access article distributed under the terms and conditions of the Creative Commons Attribution license (http://creativecommons.org/licenses/by/3.0/). 